\title{
The Analysis of Altman Model and Ohlson Model in Predicting Financial Distress of Manufacturing Companies in the Indonesia Stock Exchange
}

\author{
Elsa Imelda* and Clara Ignacia Alodia \\ Tarumanagara University, Jakarta, Indonesia
}

\begin{abstract}
The purpose of this research is to examine the accuracy of the Altman Model and the Ohlson Model in Bankruptcy Prediction. The research population is all companies who are listed on the Indonesian Stock Exchange. The sample of the research is 40 manufacturing companies listed on the Indonesian Stock Exchange in the period of 2010-2014 that are divided into companies with financial distress and those without financial distress. The data analysis technique is the Multiple Discriminant Analysis and Logit Analysis. The Multiple Discriminant Analysis is derived from the Altman Model while the Logit Analysis is derived from the Ohlson Model. The results show that the Ohlson Model and the Logit Analysis are more accurate than the Altman Model and the Multiple Discriminant Analysis in predicting bankruptcy of manufacturing firms in the Indonesian Stock Exchange (BEI) in 2010-2014. Also, the results of the study reveal that the ratio of retained earnings to total assets; earnings before interest and taxes to total assets; market value of equity to total liabilities; sales to total assets; and debt ratio, return on assets, working capital to total assets and net income were negative in the last two years. Hence constitutes the benchmark for consideration in determining the financial distress of a company.
\end{abstract}

Keywords: Altman Model, Ohlson Model, Multiple Discriminant Analysis, Logit Analysis, Bankruptcy

JEL Classification: G140, G330

Paper Type: Research

\section{INTRODUCTION}

The development of technology and the change in the economic cycle have led the business world also to continue to improve. These changes have an impact on the fierce competition experienced by all subjects in the business community (Sinambela, 2009). A company is expected not only adapt to the circumstances but also to sustain ongoing concern in the middle of the occurring changes. Besides the changes that continue to occur, one of the problems that could become a threat for a company is bankruptcy.

* Corresponding author: E-mail: elsai@fe.untar.ac.id 
Prihanthini and Sari (2012) argued that bankruptcy is a condition in which a company can no longer afford its operation well, because of the financial distress experienced by these entities has been very severe. Elmabrok and Kim (2012) found that bankruptcy or financial distress occurs when the amount of liabilities exceeds the fair value of the assets or when current liabilities exceed current assets. Bankruptcy or financial distress experienced by most companies could have an appalling impact on the world's economy (June, 2012).

Ramadhani and Lukviarman (2009) and Ghosh (2013) stated that the characteristic of a bankrupt company is a decrease in the company's financial condition that occurs for an extended period and continuously (financial distress). According to Gamayuni (2011), the causes of financial distress can be derived from internal and external factors. The internal factors can be the lack of management experience and the lack of knowledge in managing the assets and liability effectively. While the external factors can be inflation, taxes, and legal system, and the depreciation of foreign currencies. Some parties will get harmed if a company goes bankrupt. Adriana et al. (2012) explained that the parties are investors and creditors. Therefore, we need a tool or a predictive model that can be used to detect the potential of financial distress of companies.

There are many types of research of prediction models to detect financial distress that can lead to various conditions of the company before it becomes bankrupt (Endri, 2009). These researchers help potential investors and creditors in choosing the right company and not to get caught up in the bankruptcy problem. Pradhan (2011) considered that to improve the financial condition after receiving an early warning for bankruptcy depends on the utilization capacity of some areas and the availability of financial options in the company. As stated by Nidhi and Saini (2013), the company's financial situation can be assessed by using standard financial ratios. The financial distress detection tools that can be employed are the Altman Z-Score (1968) and Ohlson (1980).

In 1968, Altman did research to find a predictive model for the financial distress that is called the Multiple Discriminant Analysis (MDA). This analysis combines several financial ratios into one model as a measure of the health of a company that consists of five ratios and then is called Z-Score. Ohlson's model has a different formula and methodology from Altman (1968). This method is the logistic regression, a statistical method used to predict the probability of an occurring event by matching the data on the logistic curve function.

From the models of financial distress above, there are differences in the prediction result. Karamzadeh (2012) concluded that the Altman's model was the better predictor between the two predictors in the analysis (Altman's model and Ohlson's model). In contrast, the previous study of Moghadam, Zadeh and Fard (2010) found that the Ohlson's model was a better predictor. Muzir and Caglar (2009) study agreed with this position as their revealed that Ohlson's model was better than the Altman's model. Based on the inconsistent results, this research is made to analyse the accuracy of the two predictors in predicting financial distress.

\section{LITERATURE OF FINANCIAL DISTRESS MODEL}

This section explained in details about the two quite common financial distress analysis models. They are the Altman's (1968) and the Ohlson's (1980).

\subsection{The Altman Z-Score (1968)}

After Beaver (1966), later Edward Altman also conducted research in financial distress. Altman (1968) did what Beaver (1966) suggested at the end of his writing, which is to 
perform multivariate analysis. The Altman's model later becomes the most popular model to predict financial distress. The model is known as the Z-Score.

Altman (1968) used Multiple Discriminant Analysis (MDA) with five types of financial ratios such as working capital to total assets, retained earnings to total assets, earnings before interest and tax, the market value of equity to total liabilities, and sales to total assets. This research used 66 companies in a period of 20 years (1946-1965) as samples. These samples were divided into two groups: 33 companies that were considered in distress and 33 other companies that were considered not to be in distress. These companies that were considered to be in distress were companies who filled bankruptcy petition by National Bankruptcy Act Chapter X. Altman (1968) only used manufacturing companies as his samples. The reason behind it is the same as Beaver (1966) that the data is available only from Moody's Industrial Manual which only contains data on manufacturing firms.

The Altman's study was able to obtain $95 \%$ prediction accuracy for the data of one year before distress, and $72 \%$ for the data of two years before distress. In addition, the companies with low profitability are potential to face financial distress. Until now, the ZScore is still more widely used by researchers, practitioners, and academics in accounting than the other prediction model. The equation of the Altman's research is:

$$
\begin{aligned}
& \mathrm{Z}=1.2 \mathrm{X}_{1}+1.4 \mathrm{X}_{2}+3.3 \mathrm{X}_{3}+0.6 \mathrm{X}_{4}+1.0 \mathrm{X}_{5} \\
& \text { Where, } \\
& \mathrm{X}_{1}=\text { Working Capital/Total Assets } \\
& \mathrm{X}_{2}=\text { Retained Earnings/Total Assets } \\
& \mathrm{X}_{3}=\text { Earnings before Interest and Taxes/Total Liabilities } \\
& \mathrm{X}_{4}=\text { Market Value of Equity/Total Liabilities } \\
& \mathrm{X}_{5}=\text { Sales/Total Assets }
\end{aligned}
$$

With criteria (Kumari \& Chaudhry, 2012):

a) Z-Score $>2.99$ as healthy public company (non-distress)

b) $1.81<Z-S c o r e<2.99$ as grey zone

c) Z-Score 1.81 as unhealthy public company (distress)

\subsection{The Ohlson Model (1980)}

Ohlson (1980), who was inspired by previous studies, also conducted a study about financial distress. However, there are some modifications that he did in his study compared with previous ones. Ohlson used data from the year 1970 to 1976 of 105 manufacturing companies that went bankrupt and 2058 companies that were not bankrupt during the period.

Besides the number of samples used, there are other differences from the data source. If Altman (1968) and Beaver (1966) used data from Moody's Manual, then Ohlson (1980) got the data from the financial statement issued for taxes (10K-Financial Statement). The service he used is Compustat. Ohlson used logit statistical method. Ohlson believed the method could cover the weakness in Multiple Discriminant Analysis method employed by Altman.

Ohlson's model has 9 (nine) variables consisting of several financial ratios. The model is:

$$
\begin{gathered}
O=-1,32-0,407 X_{1}+6,03 X_{2}-1,43 X_{3}+0,0757 X_{4}-2,57 X_{5}-1,83 X_{6} \\
+0,285 X_{7}-1,72 X_{8}-0,521 X_{9}
\end{gathered}
$$




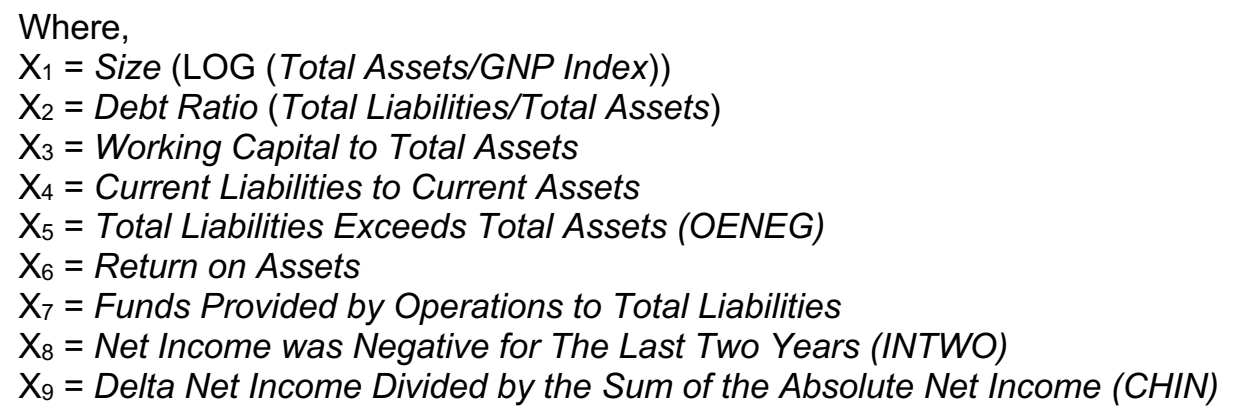

Criteria of distress:

a) $O$-Score 0.38 as non-financial distress companies

b) O-Score $>0.38$ as financial distress companies

\subsection{Logit Analysis}

Logit regression analysis is used to analyse the effect of a number independent variables on dependent variables which are categorical variables (binomial, multinomial, or ordinal) and also to predict the value of a dependent variable (in the form of categorical variable) based on the value of the independent variable. SPSS provides three logistic regression procedures:

a) Binary logistic regression: a logistic regression where the dependent variable is dichotomous variables or binary variable

b) Multinomial logistic regression: a logistic regression where the dependent variable is categorical variable comprising of more than two values

c) Ordinal logistic regression: a logistic regression in which the dependent variable is a variable with the ordinary scale

Logit analysis is a special form of regression in which the dependent variable is nonmetric and is divided into two parts or groups (binary), although the formulation may include more than two groups. In general, the interpretation of the logit analysis is very similar to the linear regression.

The logistic regression model used in this research (Moghadam, Zadeh and Fard, 2010) was derived from Ohlson's model and the model is:

Notes:

$$
\operatorname{Ln} \frac{P_{1}}{1-P_{1}}=\beta_{o}+\beta_{1} X_{1}+\beta_{2} X_{2}+\beta_{3} X_{3}+\beta_{4} X_{4}
$$

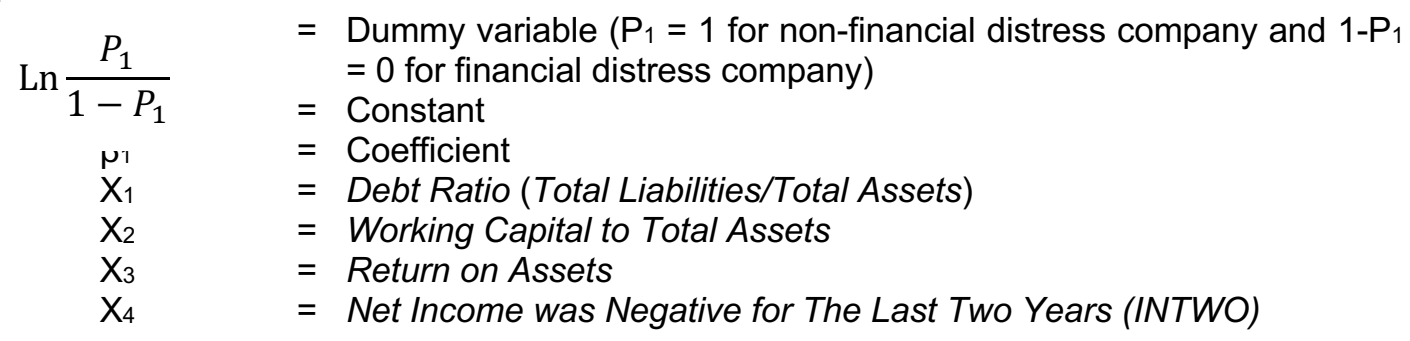

\subsection{Multiple Discriminant Analysis (MDA)}

Multiple Discriminant Analysis (MDA) is a statistical technique used to predict and explain the strong relation influence on the category in which the object has certain dependent variables (nominal or non-metric), and the independent variables are metrics. The purpose 
of MDA is to identify the minimum number of discriminant function that can maximize the difference between the groups that exist.

Multiple Discriminant Analysis is a formal methodology that is used to reduce the ratio as to enhance the representativeness of the selected financial ratios as variables. This analysis model can be used to:

1) Predict the company's bankruptcy

2) Evaluate the company's prospect

3) Assess the feasibility and reasonableness of an organizational plan in deciding alternatives

The prediction models of MDA (Moghadam, Zadeh and Fard, 2010) which derived from Altman's Model is:

Notes:

$$
\text { Z-Score }=a+b_{1} X_{1}+b_{2} X_{2}+b_{3} X_{3}+b_{4} X_{4}
$$
$\mathrm{a}=$ Intercept
$\mathrm{b}=$ coefficient
$\mathrm{X}_{1}=$ Retained Earning to Total Assets
$\mathrm{X}_{2}=$ Earnings Before Interest and Taxes to Total Assets
$\mathrm{X}_{3}=$ Market Value of Equity to Total Liabilities
$\mathrm{X}_{4}=$ Sales to Total Assets

\section{RESEARCH HYPOTHESIS}

Karamzadeh (2012) concluded that the Altman's model is the better predictor between the two predictors in the analysis (Altman's model and Ohlson's model). This is because the Altman's model has more percentage of accuracy than the Ohlson's. Therefore, the hypothesis of this research is:

$\mathrm{H}_{1}$ : The Ohlson's Model is more accurate than Altman's Modelling predicting the financial distress of manufacturing companies listed on the Indonesian Stock Exchange in 2010-2014

Since the MDA Analysis is derived from the Altman Model and the Logit Analysis stems from the Ohlson model. Therefore the second hypothesis of this research is:

$\mathrm{H}_{2}$ : The Logit Analysis is more accurate than the Multiple Discriminant Analysis in predicting the financial distress of manufacturing companies listed on the Indonesian Stock Exchange in 2010-2014

\section{RESEARCH METHODOLOGY}

The population in this study is all the manufacturing companies listed on the Indonesia Stock Exchange. The research sample is determined by predetermined criteria. The standards in this research consist of general and specific criteria. General criteria are the criteria that must be met by all samples as follows:

a) The financial statements (income statement, retained earnings statement, balance sheet, and cash flow) are available for the 5 years period (2010-2014).

b) Stock price data is accessible on the last trading date

Specific criteria are used to determine whether a company is experiencing financial distress or not. Specific criteria must be met to categorize the samples. The samples are divided into 2 (two) categories, companies that are experiencing financial distress and 
companies that are not experiencing financial distress. The specific criteria for the samples belonging to the category 1 (financial distress) are:

a) The company has a Retained Loss (negative equity). Negative equity means total liability exceeds its total assets. This is consistent with the definition of financial distress by Luciana (2006)

b) The company has negative net income for the last two years. This is in conformity with the definition of financial distress by Luciana (2006)

The specific criteria for the samples belonging to category 2 (non-financial distress) are:

a) The company does not have negative equity, or does not have negative net income for the last 2 years

b) Derived from the same year with the sample at category 1

The data used in this research is secondary data. Secondary data is the data obtained indirectly from the research object. The data obtained by the researcher are a financial statement of the company, one, two and three years before the company underwent distress. The data which is taken is manufacturing companies listed on the Indonesian stock exchange in the period 2010-2014. Because the financial distress prediction was made three years earlier, then the period of the financial distress was 2013-2014.

This research adopted independent sample t-test and the calculation of the Altman's Model and Ohlson's model to test the Hypothesis H1. The method is to compare the classification accuracy of the Altman's model and Ohlson's model. Then test the significance by using the independent sample with at-test.

This research used the Multiple Discriminant Analysis and the Logit Analysis to compare the percentage of the classification accuracy to test the Hypothesis $\mathrm{H} 2$. All of the test using statistical analysis tool of IBM Statistical Packages for the Social Science for windows version 22 (SPSS ver.22).

\section{RESEARCH RESULT AND ANALYSIS}

This section will compare the Altman's Model and Ohlson's Model for hypothesis 1 . The MDA analysis and Logit Analysis will be compared for hypothesis 2.

\subsection{The Comparison of Altman's Model and Ohlson's Model}

The Altman's model has a cut-off value of 2.99 for the public manufacturing companies (Kumari and Chaudhry, 2012). It means that if the score obtained by a company exceeds 2.99 , the company is predicted as not experiencing financial distress. Otherwise, if the score of the company is less than 2.99, then the company is predicted as experiencing financial distress.

Table 5.1. The Calculation of the Altman's Model

\begin{tabular}{|c|c|c|c|c|c|c|c|c|}
\hline \multirow{2}{*}{ Year } & \multicolumn{2}{|c|}{ Actual } & \multirow{2}{*}{ Total } & \multicolumn{2}{|c|}{ Predicted } & \multirow{2}{*}{$\begin{array}{l}\text { Grey } \\
\text { Zone }\end{array}$} & \multicolumn{2}{|c|}{ Accuracy } \\
\hline & Distress & Non-Distress & & Distress & Non-Distress & & Number & $\%$ \\
\hline 1 year before & 20 & 20 & 40 & 18 & 7 & 4 & 25 & $63 \%$ \\
\hline 2 years before & 20 & 20 & 40 & 16 & 8 & 10 & 24 & $60 \%$ \\
\hline 3 years before & 20 & 20 & 40 & 17 & 7 & 11 & 24 & $60 \%$ \\
\hline Total & 60 & 60 & 120 & 51 & 22 & 25 & 73 & - \\
\hline Mean & - & - & - & - & - & - & - & $61 \%$ \\
\hline
\end{tabular}

From the average of three years before financial distress above, the overall model of Altman can predict that are 51 companies that are experiencing financial distress from 
total 60 samples categories of financial distress and 22 companies that are not experiencing financial distress from the total 60 samples categories of non-financially distress company. Therefore, it can be concluded that the level of accuracy of Altman's model as a whole is about $61 \%$ of the number of correct predictions is 73 samples.

The Ohlson's model has a cut-off value of 0.38 , which means if the company has a score more than 0.38 , then the company is predicted to experience financial distress in the future. Otherwise, if the score is less than 0.38 , it is predicted that it will not experience financial distress in the future.

Table 5.2. The Calculation of the Ohlson's Model

\begin{tabular}{|c|c|c|c|c|c|c|c|}
\hline \multirow{2}{*}{ Year } & \multicolumn{2}{|c|}{ Actual } & \multirow{2}{*}{ Total } & \multicolumn{2}{|c|}{ Predicted } & \multicolumn{2}{|c|}{ Accuracy } \\
\hline & Distress & Non-Distress & & Distress & Non-Distress & Number & $\%$ \\
\hline 1 year before & 20 & 20 & 40 & 11 & 15 & 26 & $65 \%$ \\
\hline 2 years before & 20 & 20 & 40 & 14 & 17 & 31 & $78 \%$ \\
\hline 3 years before & 20 & 20 & 40 & 12 & 18 & 30 & $75 \%$ \\
\hline Total & 60 & 60 & 120 & 37 & 50 & 87 & - \\
\hline Mean & - & - & - & - & - & - & $73 \%$ \\
\hline
\end{tabular}

From the average of three years before financial distress above, the overall model of Ohlson can predict there are 37 companies that are experiencing financial distress from total 60 samples categories of financial distress and 55 companies that are not experiencing financial distress from total 60 samples categories of non-financial distress. Therefore, it can be concluded that the level of accuracy of Ohlson's model as a whole is about $73 \%$ of the number of correct predictions is 87 samples.

Table 5.3. The Comparison of Altman's Model and Ohlson's Model

\begin{tabular}{ccc}
\hline \multirow{2}{*}{ Year } & \multicolumn{2}{c}{ Accuracy } \\
\cline { 2 - 3 } & Altman & Ohlson \\
\hline 1 Year Before & $63 \%$ & $65 \%$ \\
2 Years Before & $60 \%$ & $78 \%$ \\
3 Years Before & $60 \%$ & $75 \%$ \\
Average & $61 \%$ & $73 \%$ \\
\hline
\end{tabular}

The test of HypothesisH1was done by using independent sample t-test for both models.

Table 5.4. Independent Sample T-test of Altman's Model and Ohlson's Model

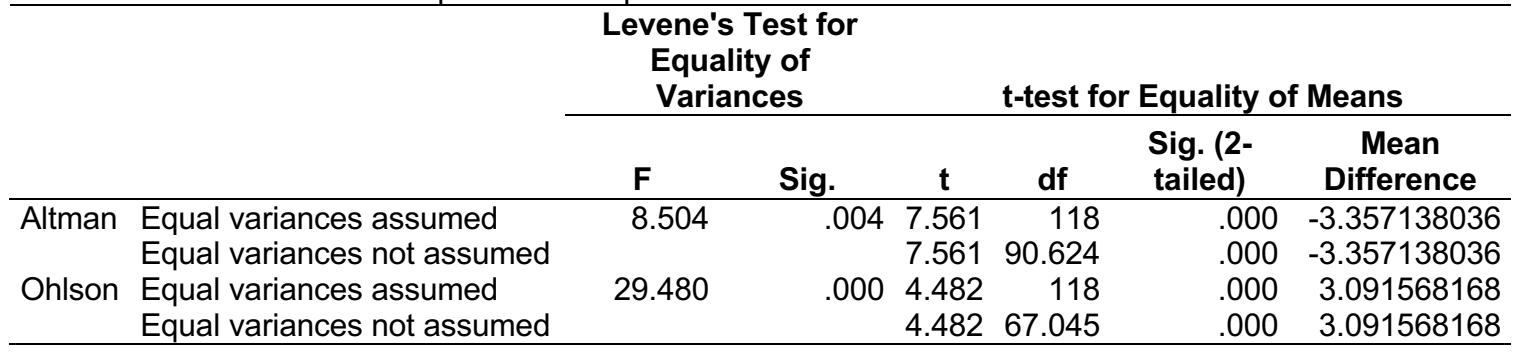

The Table 5.4 showed that the model of Altman and Ohlson significantly differentiate categories of financial distress companies with non-financial distress companies. However, since the accuracy of Ohlson's Model is bigger. Therefore the conclusion of the hypothesis in this study are as follows:

$\mathrm{Ho}_{1}$ : The Ohlson's Model is not more accurate than the Altman's Modelling predicting the financial distress on manufacturing companies listed on the Indonesian Stock Exchange in 2010-2014 
$\mathrm{Ha}_{1}$ : The Ohlson's Model is more accurate than the Altman's Modelling predicting the financial distress on manufacturing companies listed on the Indonesian Stock Exchange in 2010-2014

From the result of the calculation on both the Altman's model and Ohlson's model can be concluded that $\mathrm{HO}_{1}$ is rejected. This is consistent with the research by Moghadam, Zadeh and Fard (2010) which said that the Ohlson's model is more accurate than the Altman's model in predicting financial distress.

\subsection{The Comparison of Multiple Discriminant Analysis and Binary Logit Analysis}

The test of discriminant analysis and binary logit analysis were conducted in order to identify the variables that are able to differentiate groups, using variables that have been identified to construct the equation or function to calculate new variables or index that explain the differences between groups, and use these variables to develop new feature or how to categorize the group in future. Then the MDA and logit analysis will be compared to seek the accuracy and test the second hypothesis.

\subsubsection{Multiple Discriminant Analysis}

This research used the Multiple Discriminant Analysis and the calculation of the Altman's model as the data. Step one, determine what variables are the most efficient in differentiating between the companies that are categorized as experiencing financial distress, grey zone, and non-financially distressed. Mahalobis distance was used for the stepwise procedure to determine which variables have the greatest accuracy.

Table 5.5. Wilks' Lambda Multiple Discriminant Analysis (MDA) Model

\begin{tabular}{lllrrrrrrr}
\hline & \multirow{2}{*}{$\begin{array}{c}\text { Number of } \\
\text { Sariables }\end{array}$} & Lambda & df1 & df2 & df3 & Statistic & df1 & df2 & Sig. \\
\hline 1 & 1 & .829 & 1 & 2 & 117 & 12.035 & 2 & 117.000 & .000 \\
2 & 2 & .706 & 2 & 2 & 117 & 11.004 & 4 & 232.000 & .000 \\
3 & 3 & .499 & 3 & 2 & 117 & 15.923 & 6 & 230.000 & .000 \\
4 & 4 & .345 & 4 & 2 & 117 & 20.020 & 8 & 228.000 & .000 \\
5 & 5 & .321 & 5 & 2 & 117 & 17.297 & 10 & 226.000 & .000 \\
6 & 4 & .325 & 4 & 2 & 117 & 21.507 & 8 & 228.000 & .000 \\
\hline
\end{tabular}

Table 5.6. Selected Variable for Forming Discriminant Model

\begin{tabular}{|c|c|c|c|c|}
\hline Step & & \multicolumn{3}{|c|}{ Sig. of $F$ to } \\
\hline 6 & EBIT/TA & .976 & .001 & 2.630 \\
\hline & MARKET VALUE/TL & .729 & .000 & .380 \\
\hline & SALES/TA & .812 & .000 & 1.404 \\
\hline & RE/TA & .868 & .000 & 2.100 \\
\hline
\end{tabular}

Table 5.5 and Table 5.6 show the variable that has been chosen from five variables in the model that can be inserted in the discriminant's equation. The equation of discriminant starts from variables that have the greatest statistical $F$ number and the highest Min.D Square. F value for variable Working Capital to Total Assets is the smallest in the group, so at the final stage, variable Working Capital to Total Assets is not selected. High Mahalanobis indicates a high accuracy.

From the result of Wilk's Lambda test, variables Earnings before Interest and Taxes to Total Assets, Market Value of Equity to Total Liabilities, Sales to Total Assets, Retained Earning to Total Assets have a significant value of less than 0.05 which is 0.000 . Therefore, from the five variables, there are four variables that are significant, Earning before Interest and Taxes to Total Assets, Market Value of Equity to Total Liabilities, Sales 
to Total Assets, and Retained Earning to Total Assets. Step two, determine the equation model. From the canonical discriminant function, produce the coefficient to determine the equation model.

Table 5.7. Discriminant Function

\begin{tabular}{lr}
\hline Variable & Function \\
\hline RE/TA & .515 \\
EBIT/TA & 2.847 \\
MARKET VALUE/TL & .529 \\
SALES/TA & 1.324 \\
(Constant) & -1.879 \\
Unstandardized coefficients & \\
\hline
\end{tabular}

Table 5.7 shows there are four variables that are made as discriminant function. They are Earning before Interest and Taxes to Total Assets, Market Value of Equity to Total Liabilities, Sales to Total Assets, and Retained Earning to Total Assets. The function is:

$$
Z_{1}=-1,879+0,515 X_{1}+2,847 X_{2}-0,277 X_{3}+1,324 X_{4}
$$

Step three, canonical correlation test to measure the relationship between the value of the discriminant and the group. Canonical correlation is identical to $\mathrm{R}^{2}$ (R-Square) on a regression which measures the variation between groups that can be explained by discriminant variables. The Canonical correlation measures how strong the discriminant function.

Table 5.8. Level of Accuracy

\begin{tabular}{ccccc}
\hline Function & Eigenvalue & $\%$ of Variance & Cumulative $\%$ & $\begin{array}{c}\text { Canonical } \\
\text { Correlation }\end{array}$ \\
\hline 1 & $1.755^{\text {a }}$ & 93.7 & 93.7 & .798 \\
\hline a. First 2 canonical discriminant functions were used in the analysis.
\end{tabular}

Table 5.8 shows that the discriminant function can explain the variation of $93,7 \%$. So it can be said that the variable Earnings before Interest and Taxes to Total Assets, Market Value of Equity to Total Liabilities, Sales to Total Assets, and Retained Earning to Total Assets can explain the variation between groups of financial distress and non-financial distress.

Table 5.9. Classification Result

\begin{tabular}{|c|c|c|c|c|c|c|}
\hline & & & Predicte & roup Mer & rship & \\
\hline & Dis & ss/non-distress & 1.00 & 2.00 & 3.00 & Total \\
\hline Original & Count & Distress & 52 & 16 & 1 & 69 \\
\hline & & Greyzone & 0 & 24 & 1 & 25 \\
\hline & & Non Distress & 0 & 9 & 17 & 26 \\
\hline & $\%$ & Distress & 75.4 & 23.2 & 1.4 & 100.0 \\
\hline & & Greyzone & .0 & 96.0 & 4.0 & 100.0 \\
\hline & & Non Distress & .0 & 34.6 & 65.4 & 100.0 \\
\hline
\end{tabular}

Step four, the classification result is used to assess how well the discriminant function is Discriminant function on table 5.9 shows the average of classification accuracy for MDA is $78,93 \%$

$$
\text { Average }=\frac{75,4+96+65,4}{3}=78,93 \%
$$




\subsubsection{Binary Logit Analysis}

Binary logistic regression is the logistic where the dependent variables are dichotomous variables or binary variables. This research uses the stepwise method to analyse the most influential independent variable to dependent variable. The dependent variable has two categories, the financial distress company $=0$, and the non-financial distress company $=$ 1. This research using the calculation of Ohlson's model as the data within total 120 data.

This logit analysis will use Wald test. The purpose of this test is to determine what variables are most efficient in differentiating between companies categorized as experiencing financial distress and those not experiencing financial distress. Table 5.10 and Table5.11 show that the significance of the variables entered into the equation is less than 0.05 , and the significance of the variables removed from the equation is more than 0.05 .

Table 5.10. Wald Test Result

\begin{tabular}{|c|c|c|c|c|c|c|}
\hline Variable & B & S.E. & Wald & df & Sig. & $\operatorname{Exp}(B)$ \\
\hline TLTA & -1.939 & .867 & 5.005 & 1 & .025 & 144 \\
\hline WCTA & 4.670 & 1.799 & 6.735 & 1 & .009 & 106.652 \\
\hline NITA & 16.537 & 4.953 & 11.148 & 1 & .001 & 15196356.946 \\
\hline INTWO & -5.142 & 1.963 & 6.861 & 1 & .009 & .006 \\
\hline
\end{tabular}

\begin{tabular}{llccc}
\multicolumn{5}{c}{ Table 5.11. Variables Removed from the Equation } \\
\hline \multicolumn{1}{c}{ Variables } & Score & df & Sig. \\
& Size & .134 & 1 & .715 \\
& CLCA & .193 & 1 & .660 \\
& OENEG & .095 & 1 & .757 \\
& FUTL & .212 & 1 & .645 \\
CHIN & .727 & 1 & .394 \\
\hline
\end{tabular}

The table 5.10 shows that there are four significant independent variables: Debt Ratio, Working Capital to Total Assets, Return on Assets, and Net Income were Negative for The Last Two Years (INTWO). The function of Logit analysis is:

$$
\operatorname{Ln} \frac{P_{1}}{1-P_{1}}=1,01-1,939 \text { TLTA }+4,67 \text { WCTA }+16,537 \text { NITA }-5,142 \text { INTWO }
$$

The Cox and Snell R Square and Nagelkerke R Square can be interpreted as R Square on multiple regression. Table 5.12 shows that Cox and Snell $R$ Square is 0.525 , which means that all four independent variables (Debt Ratio, Working Capital to Total Assets, Return on Assets and Net Income were Negative for The Last Two Years (INTWO)) in logit analysis and can explain financial distress by $52,5 \%$. While Nagelkerke R Square can explain financial distress by $70 \%$, better than using Cox and Snell R Square.

Table 5.12. Cox \& Snell R Square and Nagelkerke R Square

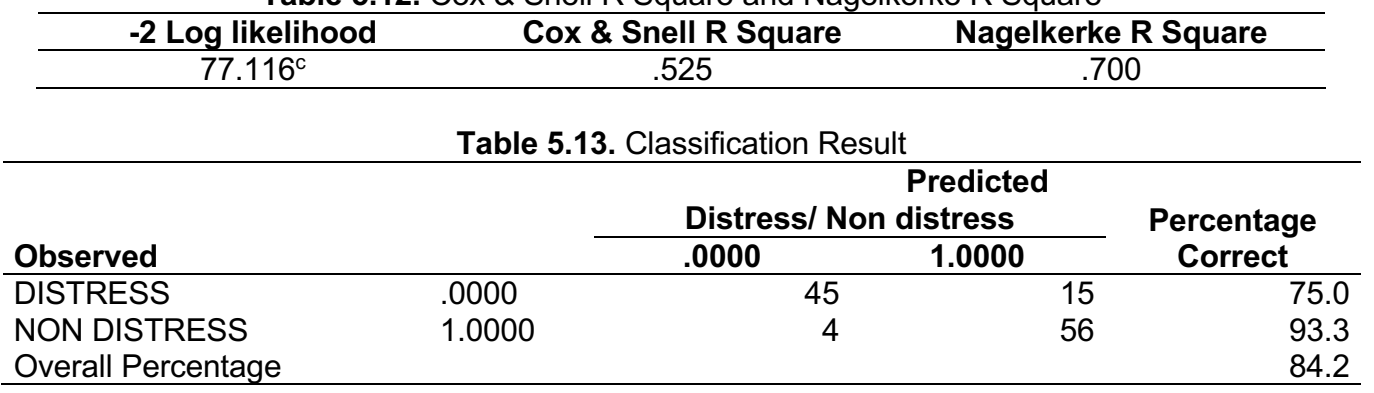


By using four variables in this model, variables Debt Ratio, Working Capital to Total Assets, Return on Assets and Net Income were Negative for The Last Two Years (INTWO) shows that the overall accuracy of a prediction model for logit analysis is $84,2 \%$.

\subsubsection{Multiple Discriminant Analysis and Logit Analysis Classification Result}

Table 5.14. Table Multiple Discriminant Analysis and Logit Analysis Classification Result

\begin{tabular}{lc}
\hline & Accuracy (\%) \\
\hline Multiple Discriminant Analysis & $78,93 \%$ \\
Logit Analysis & $84,2 \%$ \\
\hline
\end{tabular}

$\mathrm{Ha}_{2}$ : Logit Analysis is more accurate than Multiple Discriminant Analysis in predicting the financial distress on manufacturing companies listed on the Indonesian Stock Exchange in 2010-2014

$\mathrm{HO}_{2}$ : Logit Analysis is not more precise than Multiple Discriminant Analysis in predicting the financial distress on manufacturing companies listed in Indonesian Stock Exchange in 2010-2014

The Table 5.14 shows that the Logit Analysis has a greater accuracy than the Multiple Discriminant Analysis. Therefore, $\mathrm{HO}_{2}$ is rejected. This is consistent with Moghadam, Zadeh and Fard (2010) which said that the Logit Analysis is more accurate than the Multiple Discriminant Analysis.

\section{CONCLUSION AND RECOMMENDATION}

\subsection{Conclusion}

Based on the result, this study concluded that the Ohlson's Model is more accurate than the Altman's Model in predicting financial distress on manufacturing companies listed on the Indonesian Stock Exchange in 2010-2014. This is relevant with Moghadam, Zadeh and Fard (2010) which said that the Ohlson's model is more accurate in predicting financial distress than the Altman's model. However, it is not relevant with Karamzadeh (2013) which said that the Altman's model is more accurate than the Ohlson's model in predicting the financial distress.

Moreover, the result of this study also concluded that the Logit analysis model is more accurate than the Multiple Discriminant Analysis in predicting financial distress on manufacturing companies listed on the Indonesian Stock Exchange in 2010-2014. This is relevant with Moghadam, Zadeh and Fard (2010) which said that the Logit analysis model is more accurate than the Multiple Discriminant Analysis in predicting financial distress.

The result also concluded that the variables Retained Earning to Total Assets, Earning before Interest and Taxes to Total Assets, Market Value of Equity to Total Liabilities, Sales to Total Assets are significant to financial distress. While variable Working Capital to Total Asset in Multiple Discriminant Analysis model is not significant to financial distress.

Variables Debt Ratio, Return on Assets, Working Capital to Total Assets, and Net Income were Negative for The Last Two Years (INTWO) in Logit Analysis model are significant to financial distress. While variables Current Liabilities to Current Assets, Total Liabilities Exceeds Total Assets (OENEG), Funds Provided by Operations to Total Liabilities (FUTL), Delta Net Income Divided by The Sum of The Absolute Figures of Nominator (CHIN) are not significant to financial distress.

Based on the conclusion above, it can provide information for investors and creditors in making investment decision with more attention to ratio Retained Earning to Total 
Assets, Earning Before Interest and Taxes to Total Assets, Market Value of Equity to Total Liabilities, Sales to Total Assets in Multiple Discriminant Analysis, and Debt Ratio, Return on Assets, Working Capital to Total Assets, and Net Income was Negative for The Last Two Years (INTWO) in Logit Analysis. Investors would be better use the Ohlson's Model and Logit analysis in predicting financial distress because they have a higher accuracy than the Altman's Model and the Multiple Discriminant Analysis.

\subsection{Recommendation}

There are some limitations that require improvement in this research. These limitations include 1) The number of samples is limited to manufacturing companies, 2) The models used are only 2 (two), but there are some other models that have been found, 3) The criteria financial distress is still not fixed to differentiate between financially distressed companies and non-financially distressed ones.

Based on the limitations described above, there are some suggestions for the future research. Future studies are expected to consider a broader sampling, for example, using a sample of other companies than manufacturing companies, such as banking or services. So, it can provide a broader view of the financial distress model in other industrial fields. Future studies are expected to use other financial distress prediction models that are rarely used but affect financial distress. Future studies are also expected to add more criteria for financial distress so that the result will be more accurate.

\section{REFERENCES}

Adriana, Azwir, Nasir dan Rusli (2012). Analisis Prediksi Kebangkrutan Menggunakan Metode Springate Pada Perusahaan Foods and Beverages Yang Terdaftar Di Bursa Efek Indonesia Periode 2006-2010. Jurnal Repository. Fakultas Ekonomi Universitas Riau

Almilia, Luciana Spica. (2006). Prediksi Kondisi Financial Distress Perusahaan Go-Public Dengan Menggunakan Analisis Multinomial Logit. Jurnal Ekonomi dan Bisnis.12 (1).

Altman, Edward I. (1968). Financial Ratios: Discriminant Analysis and the Prediction of Corporate Bankruptcy. Journal of Finance Edition123 September.

Beaver, William. (1966) Financial Ratios as Predictors of Failures. Journal Accounting Research: 71-111.

Elmabrok, A. A. M and Ng. Kim-Soon (2012). Using Altman's Model and Current Ratio to Assess the Financial Status of Companies Quoted In the Malaysian Stock Exchange. International Journal of Scientific and Research Publications, 2(7). Faculty of Technology Management, Business and Entrepreneurship University Tun Hussein Onn Malaysia

Endri. (2009). Prediksi Kebangkrutan Bank Untuk Menghadapi Dan Mengelola Perubahan Lingkungan Bisnis: Analisis Model Altman's Z-Score. Perbanas Quarterly Review, 2(1)

Gamayuni, Rindu Rika. (2011). Model Altman sebagai Alat untuk Memprediksi Kebangkrutan (Studi Empiris pada Perusahaan Manufaktur di BEI).Jurnal Akuntansi Dan Keuangan, 16(2). Fakultas Ekonomi Universitas Lampung

Ghosh, Partha. (2013). Testing of Altman's Z - Score model, a Case Study of Dunlop India Ltd. Paripex-Indian Journal of Research, 3(4). Faculty, Department of Business Administration, George College of Management and Science, Kolkata

June Li. (2012). Prediction of Corporate Bankruptcy from 2008 through 2011. Journal of Accounting and Finance.12 (1). University of Wisconsin, River Falls

Karamzadeh, Mani Shehni. (2012). Application and Comparison of Altman and Ohlson Models to Predict Bankruptcy of Companies. Research Journal of Applied Sciences, Engineering, and Technology, 5(6).ISSN: 2040-7459

Kumari, M.U. and Chaudhry, Omvir. (2012). Distress Prediction Model-Model for Predicting Bankruptcy in Aviation Industry. International Journal of Emerging Research in Management \& Technology. ISSN: 22789359 
Moghadam, A. G., Gholampour, M. M., \& Zadeh, F. N. (2010). Review of the prediction power of Altman and Ohlson Models in predicting bankruptcy of Listed Companies in Tehran Stock Exchange. The International Management Conference. Ferdowsi University of Mashhad.

Muzir, GrvErol and Caglar, Nazan. (2009). The accuracy of financial distress prediction models in turkey: a comparative investigation with simple model proposals. Anadolu University Journal of Social Science Vol. 9

Nidhi, Aorora and Saini, Jatinderkumar R. (2013). Time series model for bankruptcy prediction via adaptive neuro-fuzzy inference system. International Journal of Hybrid Information Technology, 6(2). India

Ohlson, James A. (1980). Financial ratios and probabilistic prediction of bankruptcy. Journal of Accounting Research. 18(1): 109-131.

Pradhan, Roil. (2011). Prediction of z-score for private sector banking firms. International Referred Research Journal, 2(22). ISSN-0975-3486, RNI: RAJBIL 2009/30097

Prihanthini, Ni Made Evi Dwi and Sari. Maria M. Ratna. (2012). Prediksi Kebangkrutan dengan Model Grover, Altman Z-Score, Springate, Zmijewskipada Perusahaan Food and Beverage di Bursa Efek Indonesia. E-Jurnal Akuntansi Universitas Udayana 5.2:417-435

Ramadhani, Ayu Suci and Lukviarman, Niki. (2009). Perbandingan Analisis Prediksi Kebangkrutan Menggunakan Model Altman Pertama, Altman Revisi, Dan Altman Modifikasi Dengan Ukuran Dan Umur Perusahaan Sebagai Variabel Penjelas (Studi Pada Perusahaan Manufaktur Yang Terdaftar Di Bursa Efek Indonesia). Jurnal Siasat Bisnis, 13(1). Fakultas Ekonomi, Universitas Andalas

Sinambela, Sarton. (2009). Prediksi Kebangkrutan Perusahaan Makanan Dan Minuman: Dengan Pendekatan Model Altman Pada Perusahaan Yang Tercatat di Bursa Efek Indonesia Periode 2003-2007. Majalah Forum IImiah. 3(7).Fakultas Ekonomi Universitas Mpu Tantular 